\title{
Correction to: Towards developing digital interventions supporting empathic ability for children with autism spectrum disorder
}

\author{
Seung Jin Chung ${ }^{1} \cdot$ Gheorghita Ghinea ${ }^{2}(\mathbb{D}$
}

Published online: 3 November 2020

(c) Springer-Verlag GmbH Germany, part of Springer Nature 2020

\section{Correction to: Universal Access in the Information Society https://doi.org/10.1007/s10209-020-00761-4}

The original article has published online with incorrect affiliation of corresponding author. The correct affiliation for Gheorghita Ghinea is Brunel University, London, UK.

The original article has been corrected.

Publisher's Note Springer Nature remains neutral with regard to jurisdictional claims in published maps and institutional affiliations.

The original article can be found online at https://doi.org/10.1007/ s10209-020-00761-4.

Gheorghita Ghinea

george.ghinea@brunel.ac.uk

Seung Jin Chung

sj101js@yonsei.ac.kr

1 Yonsei University, Seoul, South Korea

2 Brunel University, London, UK 